\title{
Environmental Federalism: A Panacea or Pandora's Box for Developing Countries?
}

\author{
Per G. Fredriksson* \\ University of Louisville \\ Muthukumara Mani \\ The World Bank \\ Jim R. Wollscheid \\ Texas A\&M University - Kingsville
}

\begin{abstract}
This paper provides new empirical evidence to the debate on the optimal locus of power over environmental policymaking in developing countries. We develop a simple lobby group model with mobile capital. The model predicts that a decentralized institutional structure leads to weaker environmental policy due to more intensive lobbying by capital owners and workers. We test this prediction using novel cross-sectional developing country data. The results are consistent with the prediction of the model, in particular for air pollution policies. Moreover, we also find that the effect of decentralization declines with a greater degree of trade openness. We believe this is the first developing country evidence on the environmental policy effects of federalism.
\end{abstract}

Keywords: Federalism, Capital Competition, Lobbying, Political Economy, Environmental Policy.

JEL Codes: Q28, F21, R38, D72, D78

World Bank Policy Research Working Paper 3847, February 2006

The Policy Research Working Paper Series disseminates the findings of work in progress to encourage the exchange of ideas about development issues. An objective of the series is to get the findings out quickly, even if the presentations are less than fully polished. The papers carry the names of the authors and should be cited accordingly. The findings, interpretations, and conclusions expressed in this paper are entirely those of the authors. They do not necessarily represent the view of the World Bank, its Executive Directors, or the countries they represent. Policy Research Working Papers are available online at http://econ.worldbank.org.

Corresponding author: Muthukumara Mani (mmani@worldbank.org)

* We thank Richard Damania, Kirk Hamilton, Sushenjit Bandyopadhyay and Angeliki Kourelis for helpful comments, and Eric Neumayer and Giovanni Ruta for kindly making some of the data available. 


\section{INTRODUCTION}

The choice of the optimal locus of power over environmental policies continues to attract attention in academic and public policy debates. Should environmental policymaking be centralized or decentralized? The theoretical literature has so far failed to converge on a consensus recommendation regarding the optimal government level of environmental policymaking. Some argue that a race-to-the-bottom in environmental policies will result from decentralized environmental policymaking, while others suggest a race-to-the-top. ${ }^{1}$ Others argue that decentralized and centralized systems lead to equivalent policy outcomes. ${ }^{2}$ Neither has a clear empirical prediction emerged. ${ }^{3}$ Moreover, the literature has ignored the empirical outcomes under different regulatory designs in developing countries. ${ }^{4}$ In this paper, we ask: do developing countries with decentralized systems set environmental policies with different degree of stringency than centralized lower-income countries? We believe that this paper may both fill a gap in the literature, and help underpin the policy debate in developing countries.

\footnotetext{
1 See, e.g., Oates and Schwab (1988), Rauscher (1994), Levinson (1997), Markusen et al. (1993, 1995), Glazer (1999), Ulph (2000), McAusland (2002), and Kunce and Shogren $(2002,2005)$ for theoretical models yielding such different predictions due to, e.g., the presence of capital competition and transboundary pollution.

${ }^{2}$ See Fredriksson and Gaston (2000).

3 The existing empirical evidence comes mainly from the U.S. E.g., List and Gerking (2000) report that state level pollution levels did not deteriorate as a result of President Reagan decentralizing environmental policymaking, and Millimet (2003) finds no impact on abatement costs of this event. Fredriksson and Millimet (2002) find evidence of strategic interaction in environmental policymaking among U.S. states, Fredriksson et al. (2004) suggest that this interaction may encompass several policy instruments (also non-environmental), while Sigman (2005) find free riding behavior by U.S. states' implementation of the Clean Water Act. Oates (2001) reports that U.S. states have introduced environmental regulations that go beyond federal requirements. Additional evidence includes Murdoch and Sandler (1997) and Murdoch et al. (1997) who find evidence of free-riding in European countries' control of pollution emissions, Sigman (2002) who argues that countries free-ride in their river pollution clean-up efforts, and Eliste and Fredriksson (2004) who find some evidence indicating cross-country strategic interactions in environmental policies.

${ }^{4}$ International financial institutions such as the World Bank and IMF view decentralization as one of the most important governance and institutional reform initiatives, with a view to reform the inefficient public sector, increase competition among sub-national governments in efficient delivery of public services, and escape from low rates of economic growth (World Bank 1999, 2002). While there is no formalized theory of such a relationship between fiscal decentralization and economic growth, it is believed that policies formulated for the provision of infrastructure and education that are sensitive to regional or local conditions are likely to be more effective in
} 
To guide our empirical work, we start by deriving a theoretical prediction of the difference in environmental policy outcomes under two alternative institutional designs: centralized and decentralized government policymaking. We model a federation with two jurisdictions, where capital is mobile between jurisdictions (but immobile internationally). Our lobby group model builds on the common agency approach pioneered by Grossman and Helpman (1994, 1995). Worker, capital owner, and environmental lobby groups seek to influence environmental policy by offering the government (i.e., either the central or local government) prospective political gifts in return for a more favorable environmental policy. The government cares about social welfare, in addition to political contributions. The prediction that emerges is that environmental policy is weaker in decentralized systems. This is due to greater political pressure from the capital owners and workers under the decentralized regulatory design, induced by capital competition.

We test this prediction using unique cross-sectional developing country data on environmental policy from the World Bank (2004). This appears to be a novel approach in this literature. In our sample of 90 developing countries, we find that federations - with decentralized environmental policymaking - tend to set weaker environmental policies than centralized countries. ${ }^{5}$ This is especially the case for policies addressing air pollution. Moreover, we also

encouraging economic development than centrally determined policies that ignore geographical differences (Oates, 1993).

${ }^{5}$ For example, in India, Mexico and Nigeria decentralization is based on the political/legal structures as outlined in the constitution, specific laws, or government bills. The states or provinces have their own elected government with a wide range of fiscal powers and enforcement responsibilities, including in the environmental policy area (World Bank, 1999; Bhatt and Majeed, 2002). In contrast, countries such as Viet Nam, Bolivia, and Ghana are unitary states, where environmental enforcement is regulated through decrees or directives from the central government (World Bank, 1999). 
find that the effect of federalism is conditional on the degree of openness to trade. ${ }^{6}$ In particular, our findings suggest that the effect of decentralization is smaller in more open countries. We believe this is the first evidence of this nature in the literature.

The paper is organized as follows. Section II outlines the theoretical model and result. Section III discusses the empirical approach, while Section IV reports the empirical results. Section V provides a brief conclusion.

\section{MODEL}

Consider an economy with two jurisdictions, in each of which a large number of individuals live and work. We will denote the two jurisdictions by One and Two, respectively, where we use a "“", to denote the latter. We aim to study two different regulatory designs for these jurisdictions: (i) decentralized policy making, and (ii) centralized policy making. In the case of decentralized environmental governance, a local authority sets the standard for environmental quality; more specifically, it determines the aggregate allowed waste emissions for its own jurisdiction only. With a centralized system, a federal regulator sets a uniform emissions limit across the two jurisdictions.

Each jurisdiction contains firms that produce a private good, $Q$, for a perfectly competitive international market. Production requires inputs of capital $(K)$ and labor $(L)$, and polluting waste emissions $(\theta)$; the latter is treated as a non-purchased input. There is no spillover of pollution across jurisdictions. The production technology exhibits constant returns to scale, is concave and increasing in all inputs, and twice continuouslydifferentiable: $Q=F(K, L, \theta)$, which by linear homogeneity may be rewritten as $Q=L f(k, \alpha)$,

\footnotetext{
6 Our theory maintains an assumption of free trade. In our empirical work, we test the importance of this assumption by investigating whether the institutions of federalism has a different effect in relatively open countries. Government policy making may already has reacted to increased exposure to foreign trade.
} 
where $k=K / L$ is the capital-labor ratio and $\alpha=\theta / L$ is the emissions-labor ratio. Suppressing arguments and using subscripts to denote partial derivatives, the marginal products of capital, emissions, and labor are given by $f_{k}, f_{\alpha}$, and $\left(f-k f_{k}-\alpha f_{\alpha}\right)$, respectively. The marginal products are diminishing, i.e., $f_{k k}<0, f_{\alpha \alpha}<0$, and we assume that $f_{k \alpha}>0$, i.e., increases in $\alpha$ raise the marginal product of capital.

While labor is assumed immobile, the capital stock is perfectly mobile between the two jurisdictions, but immobile internationally. ${ }^{7}$ The rate of return on capital is equalized across both jurisdictions, whether a decentralized or centralized regime is in place. Formally, the common rate of return, $r$, must satisfy $r=f_{k}(k, \alpha)=f_{k}^{*}\left(k^{*}, \alpha^{*}\right)$. While a local policy-maker is concerned with the impact of more stringent local environmental standards on capital flows from their jurisdiction, a national policy-maker need not be concerned with capital flight. We assume that the economy has an aggregate capital stock equal to $\bar{K}$.

We assume that there are three types of individuals in each jurisdiction: workers, environmentalists, and capital owners. Normalizing the population in each jurisdiction (or in the economy, when appropriate) to unity, let $\beta^{W}, \beta^{E}$, and $\beta^{K}$ represent the proportion of the population that are workers, environmentalists, and capital owners, respectively. The environmentalists' aggregate income, $Y^{E}$, is exogenously determined. Workers supply one unit of labor and are paid a wage equal to the sum of the marginal product of labor plus the additional output arising from the increase in allowable pollution emissions, $\alpha f_{a}$, hence, wage income equals $w=f-k f_{k}$. All individuals gain utility from consuming the polluting good, but

7 A high degree of international capital immobility is a well-established empirical regularity, see for example Feldstein and Horioka (1980) and Gordon and Bovenberg (1996). 
environmentalists also suffer disutility from the pollution associated with local production. Individuals are assumed to have additively-separable utility functions $U^{i}=c^{i}-\lambda^{E} \theta$, where $i=W, E$, and $K$ index workers, environmentalists, and capital owners, respectively, and $\lambda^{E}=1$ for environmentalists ( 0 , otherwise).

\section{Centralized Policymaking}

We start by investigating the environmental policy set in the centralized system of environmental policy making. In this case, the return to (the fixed amount of) capital is simply given by $f_{k}$, and changes in environmental policies induce no capital flows between jurisdictions.

We assume that the workers, environmentalists, and capital owners in the economy (i.e., in both jurisdictions) all overcome free-rider problems and form their own separate lobby groups that encompass all individuals in both jurisdictions One and Two. In the first stage of a two-stage game, the organized lobbies offer the central government political contribution schedules $C^{i}(\alpha), i=W, E, K$, that relate prospective contributions to the environmental policy chosen by the central government (see, e.g., Damania, 2001). In the second stage, the government sets its optimal environmental policy, and collects the corresponding contributions from each lobby.

The gross welfare functions for the lobby groups are given by

$$
\begin{aligned}
V^{W}(\alpha) & \equiv \beta^{W}\left(f-k f_{k}\right) \\
V^{E}(\alpha) & \equiv Y^{E}-\beta^{E} \theta \\
V^{K}(\alpha) & \equiv \bar{K} f_{k}
\end{aligned}
$$

The central government is assumed to derive utility from a weighted sum of campaign contributions and aggregate social welfare, i.e.,

$$
V^{G}(\alpha) \equiv a V^{i}(\alpha)+\sum_{i=W, E, K} C^{i}(\alpha),
$$


where $a \geq 0$ is the government's weighting on social welfare relative to campaign contributions. Under the centralized system, the effect of relaxing the pollution standard on the worker lobby, capital owner lobby, and environmental lobby, respectively, is given by (where $\beta^{W}=L$ ):

$$
\begin{aligned}
& V_{\alpha}^{W}(\alpha)=\beta^{W}\left(f_{\alpha}-k f_{k \alpha}\right) ; \\
& V_{\alpha}^{E}(\alpha)=-\beta^{W} \beta^{E} ; \\
& V_{\alpha}^{K}(\alpha)=\beta^{W} k f_{k \alpha} .
\end{aligned}
$$

Expression (5) shows that workers' wage income rises with a more lax environmental standard in proportion to the rise in total output, minus the capital owners' share of this increase; (7) suggests the latter group benefits from a rise in the marginal productivity of capital. The environmentalists are firmly against a weaker standard, see (6).

The subgame perfect Nash equilibrium in the widely known model by Grossman and Helpman (1994) may be shown to equal the maximization of a weighted sum of the lobby groups' objective functions, where the first-order condition (assuming an interior solution) equals

$$
\sum_{i=W, E, K}(1+a) V_{\alpha}^{i}(\alpha)=0
$$

Equation (8) represents the equilibrium characterization of the emissions-labor ratio. Substituting expressions (5)-(7) into (8) and canceling terms reveals that under a centralized institutional arrangement, the environmental policy is set such that

$$
f_{\alpha}=\beta^{E}
$$

Thus, in equilibrium the marginal product of pollution, given by $f_{\alpha}$, equals its marginal social damage, given by $\beta^{E}$. Next, we turn to the decentralized system.

Decentralized Policymaking 
Under the decentralized system of environmental policymaking, the two jurisdictions are induced to compete for the available mobile capital stock. We now assume that the workers, environmentalists, and capital owners form separate lobby groups in each of the two jurisdictions. In the first stage, these lobby groups simultaneously and non-cooperatively offer their respective local governments contributions schedules relating the size of the political transfer to the policy selected, taking as given all other lobbies' schedules. In the second stage, the two local governments set their favored policies and collect the corresponding contributions.

The marginal productivity of the jurisdiction One's capital stock, $f_{k}$, must in equilibrium be equal to the marginal productivity of jurisdiction Two's capital stock, $f_{k}^{*}$. Since the overall stock of capital, $\bar{K}$, is fixed, an increase in jurisdiction One's capital stock (due to a more lax environmental policy, for example) necessarily results in a decrease in jurisdiction Two's capital stock. Using $f_{k}(k, \alpha)=f_{k}^{*}\left(k^{*}, \alpha^{*}\right)$, comparative statics yields $\frac{d k}{d \alpha}=-\frac{f_{k \alpha}}{f_{k k}+f_{k k}^{*}}>0$, since $d k^{*} / d k=-1$. Thus, under a decentralized regime, there are additional incentives for workers and capital owners to lobby for more lax environmental standards relative to the centralized system. However, the environmental lobby's marginal lobbying incentive remains constant. In particular, the effect of a more lax environmental standard on the worker, environmental, and capital owner lobby groups' utility functions are now given by, respectively,

$$
\begin{aligned}
& V_{\alpha}^{W}(\alpha)=\beta^{W}(f_{\alpha}-k f_{k \alpha}+\underbrace{\frac{k f_{k k} f_{k \alpha}}{f_{k k}+f_{k k}^{*}}}_{A}) ; \\
& V_{\alpha}^{E}(\alpha)=-\beta^{W} \beta^{E} ;
\end{aligned}
$$




$$
V_{\alpha}^{K}(\alpha)=\beta^{W}(k f_{k \alpha}-\underbrace{\frac{k f_{k k} f_{k \alpha}}{f_{k k}+f_{k k}^{*}}}_{B} \underbrace{\frac{f_{k} f_{k \alpha}}{f_{k k}+f_{k k}^{*}}}_{C}) .
$$

We now seek to compare these effects with the corresponding results for the centralized setting (see Eqns. (5)-(7)). The (additional) positive term $A$ in expression (8) suggests that the worker lobby has an additional incentive to lobby for lax regulation due to the potential inflow of capital (and thus higher productivity of labor). The negative term $B$ in expression (12) is the capital owner's corresponding disincentive to receive more capital in the jurisdiction, as this lowers the productivity of the existing capital stock. The positive term $C$ represents the capital owners' additional incentive to lobby for weaker regulation due to the fact that the newly arrived capital becomes relatively more productive.

Finally, note that in the case of symmetry (two identical jurisdictions), in equilibrium no capital flows occur (capital would only flow in the presence of some form of asymmetry in lobbying efforts). The worker and capital owner lobby groups nevertheless have an incentive engage in lobbying, as their interests otherwise would suffer.

The subgame perfect Nash equilibrium in the decentralized case corresponds to the equilibrium of the (large-country) non-cooperative game of Grossman and Helpman (1995). This implies that the equilibrium response of jurisdiction One to Two's equilibrium emissions standard, $\alpha^{*}$, again equals the maximization of a weighted sum of the lobby groups' objective functions. Thus, the equilibrium policy set in jurisdiction One satisfies

$$
\sum_{i=W, E, K}(1+a) V_{\alpha}^{i}\left(\alpha, \alpha^{*}\right)=0,
$$


which is its policy response to an arbitrary policy set by jurisdiction Two. Substituting expressions (10)-(12) into (13) and canceling terms reveals that under a centralized institutional arrangement, the environmental policy is set such that

$$
f_{\alpha}-\underbrace{\frac{f_{k} f_{k \alpha}}{f_{k k}+f_{k k}^{*}}}_{A}=\beta^{E} .
$$

In equilibrium, the environmental policy is set such that the marginal productivity of emissions plus the rise in the productivity of capital (term $A$ ) equals the marginal disutility of pollution.

Result

A comparison of expressions (9) and (14) yields the following prediction. In our empirical work below, we seek to test the validity of this prediction.

Prediction 1: In equilibrium, environmental policy is stricter under centralized environmental policymaking.

Proof: The left-hand side of (14) contains a positive term (term $A$ ), not included in (9). With an equal capital stock, $\bar{K}$, under centralized and decentralized institutional designs, and $\beta^{E}$ constant, the marginal productivity of emissions, $f_{\alpha}$, must be greater under centralized environmental policymaking. Thus, the stringency of environmental policy is greater under centralized environmental policymaking. Q.E.D.

\section{EMPIRICAL WORK}

Empirical Specification and Data 
The theoretical model developed in the previous section yields a testable implication of the relationship between federalism and environmental policy formation, expressed in Proposition 1. The first hypothesis to be tested is: countries practicing federalism (decentralized policy making) set less strict environmental policies than do non-federal countries.

Moreover, our simple model assumes free trade. We study the importance of this assumption by testing whether the effect of federalism is conditional on the degree of openness to trade. If the determination of environmental policies is (already) affected by greater trade openness, the impact of federalism (and thus greater capital competition) may be hypothesized to differ. In countries already heavily exposed to foreign competition in trade, federalism may have a smaller marginal effect on environmental policymaking, for example. The second hypothesis to be tested is therefore as follows: is the effect of federalism (decentralized policy making) conditional on the degree of openness to international trade?

Our objective is to test these hypotheses using cross-country data on environmental policy stringency. The benchmark empirical estimation can be formulated as,

$$
\alpha_{i}=\boldsymbol{x}_{i}^{\prime} \boldsymbol{\beta}^{x}+\beta^{\gamma} \gamma_{i}+\beta^{\lambda} \lambda_{i}+\beta^{\gamma \lambda} \gamma_{i} \lambda_{i}+\varepsilon_{i},
$$

where $\alpha_{i}$ is the stringency of environmental policy in country $i, \boldsymbol{x}_{i}$ is a vector of controls, $\gamma_{i}$ is an indicator of decentralized (federation) or centralized government organization, $\lambda_{i}$ is a measure of trade openness, and $\varepsilon_{i}$ is a zero mean error term. $\beta^{\gamma}, \beta^{\lambda}$, and $\beta^{\gamma \lambda}$ are coefficient scalars, and $\beta^{x}$ is a coefficient vector.

We now describe the variables and data used to test our hypotheses. Our measure of the stringency of environmental regulations is from the 2004 Country Policy and Institutional Assessment Index developed by the World Bank (2004). This index is one of the main criteria used by the World Bank to allocate International Development Assistance resources between 
low-income developing countries. It serves as an assessment tool for the World Bank to gauge the likely return to development assistance in specific countries. The index relies on the judgment of technical analysts to assess how well a country's policy and institutional framework fosters economic development, seeking to measure policies aimed at poverty reduction, sustainable growth and the effective use of development assistance. The emphasis is on policy actions and institutional effectiveness (i.e., laws on the book, implementation, monitoring, and enforcement), rather than outcomes. ${ }^{8}$ One of the 20 separate measures is "Policies and Institutions for Environmental Sustainability," which we denote Environmental Capacity. This comprehensive measure assesses the extent to which economic and environmental policies foster (i) the protection and sustainable use of natural resources, and (ii) pollution management. 9 Moreover, the aggregate measure contains separate sub-measures for air pollution, waste management, water management, coastal and marine management, biodiversity management, and commercial natural resource management. In our empirical work, we make use of both the aggregate index (Environmental Capacity), and five of the separate sub-indices (we ignore the coastal and marine management index as it is tangential to our focus). This is one of the most comprehensive data sets available measuring the environmental policy framework and institutional capacity across 90 developing countries, and has the advantage of providing sectorlevel data.

To classify centralized versus decentralized structure of government we use a dummy variable as an indicator of the federal structure of government (Federalism), which comes from

\footnotetext{
${ }^{8}$ While this index is not yet public, the World Bank intends to publish the index relating to IDA countries starting 2006.

${ }^{9}$ Although specific criteria are used for the ratings carried out by experts, they remain somewhat subjective. We note however that the ratings are scrutinized carefully by World Bank staff with extensive in-country and sector knowledge.
} 
Forum of Federations (2005) (see also Fisman and Gatti, 2002). It takes a value of 1 if federation and 0 otherwise. Out of the 90 countries in our data set, 13 are federations. In for example India, Nigeria and Mexico, decentralization is based on the political and/or legal structures (the constitution, specific laws, or government bills). The states or provinces form a federation, and each such jurisdiction has its own elected government with a wide range of fiscal powers and environmental enforcement responsibilities. In contrast, countries such as Bolivia, Ghana, and Viet Nam are unitary states, where environmental enforcement is regulated through decrees or directives from the central government (World Bank, 1999). We treat all nonfederations as having centralized systems of environmental policy making.

We also utilize an alternative measure of the degree of decentralization. The number of government tiers, and the number of jurisdictions within each tier, has implications for the degree of decentralization. IMF (2002) provides information on the number of tiers, and jurisdictions within each tier. We use the number of major sub-national entities (Subnational) within a country (such as states or provinces) as a second measure of the structure of the government.

We also seek to control for demand factors and structural features of an economy that may influence environmental policy in alternative ways that are not the focus of the present paper. First, many studies have found a relationship between income and environmental quality (see, e.g., Hettige et al., 2000). We thus include the purchasing power adjusted per capita GDP as a control (GDP). Second, the greater the number of individuals located in urban centers, the greater is the aggregate exposure to pollution and thus the marginal disutility of pollution. We use percent of the population in urban areas (\%Urban) to measure this exposure. ${ }^{10}$

\footnotetext{
${ }^{10}$ No direct measure of marginal pollution damage is included since this is determined by environmental policies.
} 
Fredriksson and Svensson (2003), e.g., identify the degree of government honesty (lack of corruption) as a determinant of environmental policy outcomes in the agricultural sector. Honesty is the corruption perceptions index developed by Transparency International (2005), which measures the "perceptions of the degree of corruption as seen by business people, risk analysts, and the general public." The index is computed as the sample average of a number of different surveys assessing each country's performance. Honesty ranges from 0 (highly corrupt) to 10 (perfectly clean). We expect a negative sign.

Trade openness is often viewed as an important determinant of environmental policy and quality (see, e.g., Antweiler et al., 2001), although the direction of the effect is disputed. Our Openness index measures the fraction of imports and exports summed, relative to GDP.

Finally, Pargal and Mani (2001) and Fredriksson et al. (2005) study the influence of citizen activism and environmental lobbying on environmental policy outcomes, and Pargal and Wheeler (1996) suggest that greater community and civic involvement could complement formal regulation in strengthening environmental compliance. We use the number of environmental NGOs (ENGOs) from Europa Publications (2001) to control for environmental lobbying.

Table 1 summarizes the descriptive statistics of the variables used. The data appendix contains a further description of the data and sources.

\section{EMPIRICAL RESULTS}

We investigate empirically the implications of our model for a sample of 90 countries for which the Environmental Capacity variable and its sub-components (air pollution, waste 
management, water management, biodiversity management, and commercial natural resource management) are available. The OLS estimation results are presented in Tables 2-4. We begin by discussing the robustness of these results, using several different specification tests.

First, we test for the possible presence of endogeneity of the Honesty and Openness variables, which may bias our OLS results. We use an augmented regression test (DWH test), suggested by Davidson and MacKinnon (1993). This is carried out by including the residuals of each endogenous right-hand side variable as a function of all exogenous variables in a regression of the original model. If they are significant, endogeneity cannot be rejected. ${ }^{11}$ As reported in Tables 2-4, we can not reject the null hypothesis of exogeneity of Honesty and Openness. This suggests that our OLS results are indeed adequate for gauging the relative influences of Honesty and Openness on Environmental Capacity.

Second, we tested for heteroskedasticity using a Cook-Weisberg test (Cook and Weisberg, 1983). This is a chi-squared test of the null hypothesis that the variance is not a function of the fitted values. The null hypothesis of homoskedasticity could not be rejected at the $5 \%$ level for any of the specifications.

Third, in order to test for possible neglected nonlinearities, we conducted a version of the Ramsey Reset test for omitted variables. The version employed uses an F-test to test the null hypothesis that the coefficients on the 2 nd to 4 th powers of the explanatory variables in an augmented model are equal to zero (Wooldridge, 2002). The Ramsey Reset test indicated that a non-linear term(s) may be missing in some models. In order to deal with this issue, we included $\mathbf{G D P}^{2}$ in the relevant models (that did not pass the test). Subsequently, all specifications pass the

\footnotetext{
11 The tests are performed using a set of standard instrumental variables for Honesty such as rule of law, accountability and common law system (see La Porta et al., 1999; Persson et al., 1997; Persson and Tabellini, 1999)
} 
Ramsey Reset test, except the Ecosystem Management Models in Tables 3 and 4 and the Natural Resource Management Model in Table 3. We therefore added GDP $^{3}$ and Honesty ${ }^{2}$ in the Ecosystem Management and Natural Resource Management models. The fit then improved and they pass the Ramsey Reset test. This suggests that all three variables have a declining impact on Ecosystems and Natural Resources Management. However, as discussed below, multicollinearity issues arise. Although we report the models containing $\mathbf{G D P}^{2}$ and $\mathbf{G D P}^{3}$ for completeness, the reader needs to be aware that these particular non-linear specifications suffer from multicollinearity (see the VIF scores discussed below).

Fourth, we tested for the presence of multicollinearity between various independent variables using the variance inflation factor (VIF) method. ${ }^{12}$ As reported in Tables 2-4, the mean VIF scores range between 1.74 and 5.55 (higher in models with $\mathbf{G D P}^{2}$ ) for all models not including GDP $^{3}$ and Honesty ${ }^{2}$. Hence, we may rule out multicollinearity as a problem in all but the latter models. These latter models, which do pass the Ramsey Reset test, obviously display a high degree of multicollinerarity (VIF scores above 80). Overall, we are satisfied with the robustness displayed by the key variables of interest in our models.

Table 2 reports the results for our Environmental Capacity models. Model 1 shows support for the hypothesis that Federalism has a negative effect on overall environmental policy stringency. Subnational in Model 3 mimics this finding, suggesting that greater subnational autonomy leads to less stringent environmental policies.

and Openness, such as democracy, political freedom, economic freedom (see Fredriksson and Mani, 2004; Damania et al. 2004).

12 The VIF score is given by $1 /\left(1-\mathrm{R}^{2}\right.$ auxiliary) where $\mathrm{R}^{2}$ auxiliary is the $\mathrm{R}^{2}$ from regressing one independent variable on all other independent variables. The VIF score shows how the variance of an estimator is inflated by the presence of multicollinearity. The VIF ranges from 1.0 to infinity. VIF scores greater than 10.0 are generally seen as indicative of severe multicollinearity. 
Models 2 and 4 explore whether the effect of Federalism is conditional on the degree of exposure to international goods markets by including the relevant interactions. Both Federalism*Openness and Subnational*Openness are positive and significant, while Federalism and Subnational remain negative and significant. Thus, our results suggest that the effect of Federalism is reduced in countries that are relatively open to international trade (although the Ramsey Reset test appears to cast some doubt on Model 2). This is consistent with a view that relatively open countries are already competing more intensively with their trade partners (using environmental policies), and thus the marginal incentive for local jurisdictions to compete (nationally) is relatively lower in more open federations. Alternatively, if more open countries attract more foreign direct investment, the degree of competition for scarce capital may decline on the margin. The effect of Federalism and Subnational remains negative at the mean of Openness, however, although economically it is relatively small. For example, using Model 2 in Table 2 the marginal effect equals $\partial$ Environmental Capacity $/ \partial$ Federalism $=-0.92+$ $0.0102 \times 63.51=-0.27$. Using Model 4 , the marginal effect equals $\partial$ Environmental Capacity $/ \partial$ Subnational $=-0.023+0.0003 \times 63.51=-0.004$.

Openness is negative and significant in all models. However, note that the positive and significant coefficient on Federalism*Openness in Model 2 suggest that in federal systems (Federalism $=1)$, greater openness to trade raises Environmental Capacity ( $\partial$ Environmental Capacity/ $\partial$ Openness $=-0.0099+0.0102 \times 1=0.0003$ ), albeit by an economically insignificant amount. Again from Model 2, in centralized systems $($ Federalism $=0$ ), the marginal effect of Openness equals -0.0099 , but this is again economically insignificant. In any case, this is further evidence that the effect of trade liberalization is country specific (see, e.g., Antweiler et al., 
2001), and in this case the effect is conditional on the presence of the institution of federalism (a point not previously made in the literature, to our knowledge).

Turning to the remaining variables, we find that ENGOs is positive and significant. This suggests that environmental lobbying plays an important role for environmental policy outcomes in developing countries. This lends further support to the activities of international organizations such as the World Bank that nurture environmental NGOs in developing countries. ${ }^{13}$ On the other hand, we find that GDP is consistently positive, as one would expect from the literature (albeit the coefficient being small). We find a similar weak significance level for \%Urban. The negative sign may potentially reflect the political power of urban workers, who may favor less stringent environmental policies. Finally, Honesty is insignificant in Models 2 and 4, i.e. where the interaction terms are not included.

\section{Specific Pollutants}

We now extend our analysis by studying whether the effect of environmental federalism differs among individual pollutants. As discussed above, we have unique and detailed information (as part of the aggregate Environmental Capacity index used in the previous section) on the stringency of environmental policies used to address air pollution and water pollution, as well as the level of waste management, ecosystem management, and the management of commercial natural resources (forestry, fisheries and minerals). The basic direct results of Federalism are reported in Table 3, and in Table 4 the interaction Federalism*Openness is added. We note that the Air Pollution and Ecosystem Management

\footnotetext{
${ }^{13}$ The Critical Ecosystem Partnership Fund is a joint initiative of Conservation International, the Global Environment Facility, the Government of Japan, the MacArthur Foundation, and the World Bank. The Fund aims to create working alliances among diverse groups, to combine capacities and eliminating duplication of efforts for a comprehensive and coordinated approach to conservation challenges, to encourage local dialogue with extractive industries, to strengthen indigenous organizations, and facilitating partnerships. For further details, see www.cepf.net/xp/cepf/about_cepf/index.xml (visited September 15, 2005).
} 
sub-components of Environmental Capacity appear to drive a large share of the results reported in Table 2 (these models contain mostly significant coefficients, consistent with our Table 2 results). However, the Ecosystem Management (1) model does not pass the Ramsey Reset test, and thus we view our Air Pollution results as more reliable. Air pollution is perhaps among the first environmental problems to be easily observed by the general citizens in developing countries, and therefore among the first to be addressed. Thus, one may expect that both economic policies (such as environmental federalism) and special interests (such as environmental lobbying) may have a particular pronounced effect on this type of pollutants in lower income countries. We also note that the models in Tables 3 and 4 explain a smaller fraction of the variation in the dependent variables than in Table 2, perhaps due to the disaggregated levels of the independent variables used in Tables 3 and 4.

For the air pollution index, the results in Table 3 closely mirror the Environmental Capacity results index in Table 2, in particular regarding the effect of Federalism. In this area, centralized regimes appear to result in significantly more stringent environmental policy outcomes. Water and wastes are frequently managed in a highly decentralized manner (mostly by municipalities), and this may explain why Federalism is insignificant in these particular models.

In Table 4, Federalism has a significant effect on the stringency of air pollution regulation and ecosystem management, although the effect is negative in all models. Moreover, the effect of Federalism on these policies declines, the greater is Openness.

Turning to the control variables in Tables 3 and 4, we find that GDP growth has a significant positive effect on all forms of environmental regulations except Ecosystem Management. On the other hand, Honesty has a consistently positive effect only on Ecosystems 
Management and Natural Resource Management (in Table 4, Honesty also strengthens Waste Pollution regulation). This may explain the insignificance of some of the Honesty results in Table 2. Environmental lobbying, as captured by ENGOs, affects environmental policies addressing Air Pollution, Waste Pollution, and Ecosystem Management in a positive and strongly significant fashion (consistent with the Table 2 results). \%Urban is (negative) significant only for Waste Pollution regulation in Table 3.

\section{CONCLUSION}

As developing countries undergo or consider some form of decentralization of government responsibilities, concerns arise regarding the environmental impacts of decentralized policy making. However, empirical research underpinning the associated difficult policy decisions in developing countries is severely lacking in this policy area.

This paper seeks to evaluate the empirical effects of environmental federalism across developing countries. We develop a simple theory of environmental policy formation in centralized and decentralized systems, where worker-, capital- and environmental lobby groups compete for the favors of a semi-benevolent government. The prediction that emerges is that a decentralized government regime yields weaker environmental policy than a centralized institutional design. This is due to a greater aggregate incentive for worker- and capital-owner lobbying for less stringent environmental policy under a decentralized system. Using a novel and unique World Bank dataset, we find empirical support for this prediction. This holds especially for air pollution policies. Moreover, we also find that the effect of federalism is conditional on the degree of trade openness. In particular, the negative effect of environmental federalism falls as the degree of trade openness rises. We believe this is the first cross-country evidence of a negative effect of federal institutional designs in developing countries. 
We should note that our empirical results do not imply that centralized environmental policymaking is necessarily optimal for all countries, only that centralized countries on average set stricter environmental policy. Strong heterogeneity between a country's jurisdictions may still tilt the balance towards decentralization, for example.

Our findings do suggest that during efforts to decentralize government structures in developing countries (perhaps in order to improve service delivery in other policy areas such as health and education), environmental policymakers as well as environmental NGOs need to pay attention need to the possible detrimental effects due to excessive capital competition among lower level jurisdictions. This calls for strengthening local environmental management capacity along with broader decentralization reform programs including administrative and institutional mechanisms to handle environmental matters. Our findings also suggest that, a simultaneous trade liberalization program may reduce the negative long-term impacts on environmental policies of federalism. 
Data Appendix

\begin{tabular}{lc}
\hline Variable & Source \\
Environmental Capacity & World Bank (2004) \\
Federalism & Forum of Federations (2005) \\
\%Urban & World Development Indicators (2004) \\
GDP & World Development Indicators (2004) \\
Openness & International Trade Center, World Development Indicators (2004) \\
Honesty & Transparency International Corruption Perception Index (2004) \\
ENGOs & Europa Publications (2001). \\
Subnational & IMF Government Financial Statistics (2002) \\
Air Pollution Management & World Bank (2004) \\
Water Pollution Management & World Bank (2004) \\
Waste Management & World Bank (2004) \\
Ecosystem Management & World Bank (2004) \\
Natural Resources Management & World Bank (2004) \\
\hline
\end{tabular}




\section{REFERENCES}

Antweiler, W., B.R. Copeland, and M.S. Taylor (2001), "Is Free Trade Good for the Environment?" American Economic Review, 91(4), 877-908.

Bhatt, S. and A. Majheed (2002), eds., Environmental Management and Federalism: The Indian Experience, Delhi: Uppal Publishing House.

Cook, R.D., and S. Weisberg (1983), "Diagnostics for Heteroscedasticity in Regression," Biometrika, 70, 1-10.

Damania, Richard (2001), "When the Weak Win: The Role of Investment in Environmental Lobbying," Journal of Environmental Economics and Management, 42(1), 1-22.

Damania, Richard, Per G. Fredriksson and Muthukumara Mani (2004), "The Persistence of Corruption and Regulatory Compliance Failures: Theory and Evidence," Public Choice, 121, 363-90.

Eliste, Paavo and Per G. Fredriksson (2004), "Does Trade Liberalization Cause a Race-to-thebottom in Environmental Policies? A Spatial Econometric Analysis." Ch. 18 in Advances in Spatial Econometrics: Methodology, Tools, and Applications, edited by L. Anselin, R.J.G.M. Florax and S.J. Rey, Berlin: Springer.

Europa Publications (2001). The Environment Encyclopedia and Directory. Europa Publications Limited, London.

Feldstein, Martin S. and Charles Horioka (1980), "Domestic Savings and International Capital Flows," Economic Journal, 90, 314-29.

Forum of Federations (2005). www.forumfed.org.

Fredriksson, Per G. and Noel Gaston (2000), "Environmental Governance in Federal Systems: The Effects of Capital Competition and Lobby Groups," Economic Inquiry, 38, 501-14.

Fredriksson, Per G. and Daniel L. Millimet (2002), "Strategic Interaction and the Determination of Environmental Policy Across U.S. States," Journal of Urban Economics, 51, 101-22.

Fredriksson, Per G., John A. List, and Daniel L. Millimet (2004), "Chasing the Smokestack: Strategic Policymaking with Multiple Instruments," Regional Science and Urban Economics, 34, 387-410.

Fredriksson, Per G. and Muthukumara Mani (2004), “Trade Integration and Political Turbulence: Environmental Policy Consequences," Advances in Economic Analysis \& Policy, 4(2), Article 1.

Frediksson, Per G., Eric Neumayer, Richard Damania, and Scott Gates (2005), "Environmentalism, Democracy, and Pollution Control," Journal of Environmental Economics and Management 49(2), 343-65.

Glazer, Amihai (1999), "Local regulation may be excessively stringent." Regional Science and Urban Economics, 29(5), 553-58. 
Gordon, Roger. H., and Lans Bovenberg (1996), "Why is Capital So Immobile Internationally? Possible Explanations and Implications for Capital Income Taxation," American Economic Review, 86(5), 1057-76.

Grossman, Gene M., and Elhanan Helpman (1994), "Protection for Sale," American Economic Review, 84(4), 833-50.

Grossman, Gene M., and Elhanan Helpman (1995), "Trade Wars and Trade Talks," Journal of Political Economy 103(4), 675-708.

Hettige, H., M. Mani, and D. Wheeler (2000), "Industrial Pollution In Economic Development: The Environmental Kuznets Curve Revisited," Journal of Development Economics 62(2), 445-76.

Kunce, Mitch and Jason F. Shogren (2002), "On Environmental Federalism and Direct Emission Control," Journal of Urban Economics 51(2), 238-45.

Kunce, Mitch and Jason F. Shogren (2005), "On Interjurisdictional Competition and Environmental Federalism," Journal of Environmental Economics and Management 50(1), 212-24.

La Porta, R., F. Lopez-de-Silanes, A. Shleifer, and R. Vishny (1999), “The Quality of Government," Journal of Law, Economics, and Organization, 15, 222-79.

Levinson, Arik (1997), “A Note on Environmental Federalism: Interpreting Some Contradictory Results," Journal of Environmental Economics and Management, 33, 359-66.

List, John A. and Shelby Gerking (2000), "Regulatory Fedralism and Environmental Protection in the United States," Journal of Regional Science 40, 453-71.

International Monetary Fund (2002), Government Financial Statistics, Washington, D.C.: World Bank.

Markusen, James R., Edward R. Morey, and Nancy D. Olewiler (1993), "Environmental Policy when Market Structure and Plant Locations Are Endogenous," Journal of Environmental Economics and Management, 24(1), 69-86.

Markusen, James R., Edward R. Morey, and Nancy D. Olewiler (1995), “Competition in Regional Environmental Policies When Plant Locations are Endogenous," Journal of Public Economics 56, 55-77.

McAusland, Carol (2002), "Cross-Hauling of Polluting Factors," Journal of Environmental Economics and Management 44(3), 448-70.

Millimet, Daniel L. (2003), "Assessing the Empirical Impact of Environmental Federalism," Journal of Regional Science 43(4), 711-33.

Murdoch, J.C. and T. Sandler (2002), "A Voluntary Provision of a Pure Public Good: the Case of Reduced CFC Emissions and the Montreal Protocol," Journal of Public Economics 63, 33149.

Murdoch J.C., T. Sandler, and K. Sargent (1997), "A Tale of Two Collectives: Sulphur versus Nitrogen Oxides Emission Reduction in Europe," Economica, 64, 281-301. 
Oates, Wallace E., and Robert M. Schwab (1988), "Economic Competition Among Jurisdictions: Efficiency Enhancing or Distortion Inducing?" Journal of Public Economics, 35(3), 333-54.

Oates, Wallace E. (1993), "Fiscal Decentralization and Economic Development," National Tax Journal, 46(2), 237-43.

Oates, Wallace E. (2001), "A Reconsideration of Environmental Federalism," Resources for the Future, November 2001, Discussion Paper 01-54, Washington, D.C.: RFF.

Pargal, S. and M. Mani (2000), "Citizen Activism, Environmental Regulation, and the Location of Industrial Plants: Evidence from India," Economic Development and Cultural Change, 48(4), 829-46.

Pargal, S., and D. Wheeler (1996), "Informal Regulation of Industrial Pollution in Developing Countries," Journal of Political Economy 104, 1314-27.

Persson, T., G. Roland, and G. Tabellini (1997), "Separation of Powers and Political Accountability," Quarterly Journal of Economics, 112, 1163-1202.

Persson, T. and G. Tabellini (1999), “The Size and Scope of Government: Comparative Politics with Rational Politicians," European Economic Review, 43, 699-735.

Rauscher, Michael (1994), “On Ecological Dumping,” Oxford Economic Papers, 46(5), 822-40.

Shyamsundar, P., E. Araral, and S. Weeraratne (2005), “Devolution of Resource Rights, Poverty, and Natural Resource Management," Environment Department Working Paper No. 104, Washington, D.C.: The World Bank.

Sigman, Hilary (2002), "International Spillovers and Water Quality in Rivers: Do Countries Free Ride?" American Economic Review 92(4), 1152-59.

Sigman, Hilary (2005), "Transboundary Spillovers and Decentralization of Environmental Policies," Journal of Environmental Economics and Management, 50(1), 82-101.

Transparency International (2005). www.Transparency.org.

Ulph, Alistair (2000), "Harmonization and Optimal Environmental Policy in a Federal System with Asymmetric Information," Journal of Environmental Economics and Management, 39, 224-41.

Wooldridge, J. (2002). Econometric analysis of cross section and panel data. Cambridge: MIT Press.

World Bank (1999), World Development Report 1999/2000: Entering the $21^{\text {st }}$ Century, Washington, D.C.: The World Bank.

World Bank (2002), World Development Report 2003: Sustainable Development in a Dynamic World, Washington, D.C.: The World Bank.

World Bank (2003), “Allocating IDA Funds Based on Performance: Fourth Annual Report on IDA's Country Assessment and Allocation Process," March 2003, Washington, D.C.: The World Bank.

World Bank (2004), “Country Policy and Institutional Assessment Index,” Washington, D.C.: The World Bank. 
Table 1. Descriptive Statistics

\begin{tabular}{lccccc}
\hline Variable & Obs & Mean & Std. Dev. & Min & Max \\
Environmental Capacity & 86 & 3.59 & 0.82 & 2.21 & 5.70 \\
Federalism & 86 & 0.16 & 0.37 & 0.00 & 1.00 \\
\%Urban & 86 & 48.97 & 18.12 & 14.91 & 90.33 \\
GDP & 83 & 4434.75 & 3079.67 & 496.26 & 12447.25 \\
Openness & 85 & 64.09 & 33.51 & 14.19 & 182.37 \\
Honesty & 74 & 3.11 & 1.20 & 1.50 & 9.10 \\
ENGOs & 82 & 11.99 & 13.60 & 0.00 & 65.00 \\
Subnational & 86 & 20.94 & 17.17 & 3.00 & 89.00 \\
Air Pollution Management & 78 & 3.21 & 1.22 & 1.00 & 6.00 \\
Water Pollution Management & 84 & 3.60 & 0.92 & 1.28 & 5.40 \\
Waste Management & 82 & 3.60 & 1.15 & 1.28 & 6.00 \\
Ecosystem Management & 84 & 3.68 & 1.03 & 2.04 & 5.79 \\
Natural Resources Management & 85 & 3.60 & 0.94 & 1.83 & 6.00 \\
\hline
\end{tabular}


Table 2: Environmental Capacity Regressions

\begin{tabular}{|c|c|c|c|c|}
\hline Variable & Model 1 & Model 2 & Model 3 & Model 4 \\
\hline GDP & $\begin{array}{l}0.0001 \\
(2.6)^{* *}\end{array}$ & $\begin{array}{l}-0.0001 \\
(2.5)^{* *}\end{array}$ & $\begin{array}{l}0.0001 \\
(2.6)^{* *}\end{array}$ & $\begin{array}{l}0.0001 \\
(2.3)^{* *}\end{array}$ \\
\hline GDP $^{2}$ & & $\begin{array}{l}2.36^{*} 10^{-8} \\
(3.1)^{* * *}\end{array}$ & & \\
\hline \%Urban & $\begin{array}{c}-0.011 \\
(2.8)^{* * *}\end{array}$ & $\begin{array}{l}-0.01 \\
(1.4)\end{array}$ & $\begin{array}{c}-0.01 \\
(2.8)^{* * *}\end{array}$ & $\begin{array}{l}-0.01 \\
(2.1)^{*}\end{array}$ \\
\hline Openness & $\begin{array}{l}-0.005 \\
(1.8)^{*}\end{array}$ & $\begin{array}{l}-0.0099 \\
(3.5)^{* * *}\end{array}$ & $\begin{array}{l}-0.005 \\
(2.1)^{*}\end{array}$ & $\begin{array}{l}-0.011 \\
(2.6)^{* *}\end{array}$ \\
\hline Honesty & $\begin{array}{l}0.16 \\
(1.2)\end{array}$ & $\begin{array}{c}0.21 \\
(2.3)^{* *}\end{array}$ & $\begin{array}{l}0.15 \\
(1.1)\end{array}$ & $\begin{array}{c}0.22 \\
(1.8)^{* * *}\end{array}$ \\
\hline ENGOs & $\begin{array}{c}0.02 \\
(2.4)^{* *}\end{array}$ & $\begin{array}{c}0.02 \\
(2.3)^{* *}\end{array}$ & $\begin{array}{c}0.02 \\
(2.3)^{* *}\end{array}$ & $\begin{array}{l}-0.02 \\
(2.4)^{* *}\end{array}$ \\
\hline Federalism & $\begin{array}{l}-0.37 \\
(2.0)^{*}\end{array}$ & $\begin{array}{c}-0.92 \\
(4.2)^{* * *}\end{array}$ & & \\
\hline Subnational & & & $\begin{array}{l}-0.007 \\
(1.8)^{* * *}\end{array}$ & $\begin{array}{l}-0.023 \\
(2.4)^{* *}\end{array}$ \\
\hline $\begin{array}{l}\text { Federalism } \\
\text { * Openness } \\
\end{array}$ & & $\begin{array}{l}0.0102 \\
(3.7)^{* * *}\end{array}$ & & \\
\hline $\begin{array}{l}\text { Subnational } \\
* \text { Openness } \\
\end{array}$ & & & & $\begin{array}{l}0.0003 \\
(1.9)^{*}\end{array}$ \\
\hline Constant & $\begin{array}{c}3.23 \\
(8.4)^{* * *}\end{array}$ & $\begin{array}{c}3.66 \\
(10.9)^{* * *}\end{array}$ & $\begin{array}{c}3.41 \\
(7.7)^{* * *}\end{array}$ & $\begin{array}{c}3.52 \\
(8.3)^{* * *}\end{array}$ \\
\hline No. of Obs. & 71 & 71 & 71 & 71 \\
\hline $\mathrm{R}^{2}$ & 0.508 & 0.612 & 0.502 & 0.525 \\
\hline $\begin{array}{l}\text { DWH Test } \\
\text { Honesty }\end{array}$ & $\begin{array}{l}\mathrm{F}(1,58)=0.24 \\
p \text { value }=0.6257\end{array}$ & $\begin{array}{l}\mathrm{F}(1,57)=0.25 \\
p \text { value }=0.6182\end{array}$ & $\begin{array}{l}\mathrm{F}(1,58)=0.10 \\
p \text { value }=0.7494\end{array}$ & $\begin{array}{l}\mathrm{F}(1,57)=0.06 \\
p \text { value }=0.8037\end{array}$ \\
\hline $\begin{array}{l}\text { DWH Test } \\
\text { Openness }\end{array}$ & $\begin{array}{l}\mathrm{F}(1,58)=0.77 \\
p \text { value }=0.3831\end{array}$ & $\begin{array}{l}\mathrm{F}(1,57)=0.80 \\
p \text { value }=0.3737\end{array}$ & $\begin{array}{l}\mathrm{F}(1,58)=0.57 \\
p \text { value }=0.4539\end{array}$ & $\begin{array}{l}\mathrm{F}(1,57)=0.01 \\
p \text { value }=0.9307\end{array}$ \\
\hline $\begin{array}{l}\text { Ramsey } \\
\text { Reset Test }\end{array}$ & $\begin{array}{l}\mathrm{F}(3,63)=1.47 \\
p \text { value }=0.2320\end{array}$ & $\begin{array}{l}\mathrm{F}(3,59)=1.91 \\
p \text { value }=0.1386\end{array}$ & $\begin{array}{l}\mathrm{F}(3,63)=0.56 \\
p \text { value }=0.6403\end{array}$ & $\begin{array}{l}\mathrm{F}(3,62)=1.18 \\
p \text { value }=0.3236\end{array}$ \\
\hline Mean VIF & 1.76 & 5.39 & 1.81 & 3.89 \\
\hline
\end{tabular}

Notes: The dependent variable is Environmental Capacity. t-statistics in parenthesis.

*** $(* *)[*]$ Statistically significant at $1(5)[10]$ percent level. 
Table 3: Individual Pollutant Regressions

\begin{tabular}{|c|c|c|c|c|c|c|c|}
\hline Variable & $\begin{array}{c}\text { Air } \\
\text { Pollution }\end{array}$ & $\begin{array}{c}\text { Water } \\
\text { Pollution }\end{array}$ & $\begin{array}{c}\text { Waste } \\
\text { Pollution }\end{array}$ & $\begin{array}{l}\text { Ecosystem } \\
\text { Mgmt (1) }\end{array}$ & $\begin{array}{c}\text { Ecosystem } \\
\text { Mgmt (2) }\end{array}$ & $\begin{array}{c}\text { Natural } \\
\text { Resource } \\
\text { Mgmt (1) }\end{array}$ & $\begin{array}{c}\text { Natural } \\
\text { Resource } \\
\text { Mgmt (2) }\end{array}$ \\
\hline GDP & $\begin{array}{c}0.0002 \\
(2.7) * * *\end{array}$ & $\begin{array}{l}0.0001 \\
(2.1)^{*}\end{array}$ & $\begin{array}{c}0.00008 \\
(1.7) *\end{array}$ & $\begin{array}{c}-0.0002 \\
(2.0)^{*}\end{array}$ & $\begin{array}{l}-0.0006 \\
(2.5) * *\end{array}$ & $\begin{array}{c}-0.0001 \\
(1.1) \\
\end{array}$ & $\begin{array}{c}-0.00007 \\
(0.01)\end{array}$ \\
\hline $\mathbf{G D P}^{2}$ & & & & $\begin{array}{l}2.71 * 10^{-8} \\
(3.1)^{* * *}\end{array}$ & $\begin{array}{l}1.21 * 10^{-7} \\
(2.2)^{*}\end{array}$ & $\begin{array}{l}2.06 * 10^{-8} \\
(2.8)^{* * *}\end{array}$ & $\begin{array}{c}5.17 * 10^{-10} \\
(0.01)\end{array}$ \\
\hline GDP $^{3}$ & & & & & $\begin{array}{c}-5.35^{*} 10^{-12} \\
(1.9)^{*}\end{array}$ & & $\begin{array}{c}1.03 * 10^{-12} \\
(0.5)\end{array}$ \\
\hline \%Urban & $\begin{array}{c}-0.007 \\
(1.2) \\
\end{array}$ & $\begin{array}{c}-0.007 \\
(1.0) \\
\end{array}$ & $\begin{array}{l}-0.01 \\
(1.7)^{*}\end{array}$ & $\begin{array}{c}-0.003 \\
(0.4) \\
\end{array}$ & $\begin{array}{c}-0.0006 \\
(0.1)\end{array}$ & $\begin{array}{c}-0.001 \\
(0.3) \\
\end{array}$ & $\begin{array}{c}-0.00004 \\
(0.01)\end{array}$ \\
\hline Openness & $\begin{array}{l}0.0001 \\
(0.03)\end{array}$ & $\begin{array}{l}-0.004 \\
(1.3)\end{array}$ & $\begin{array}{c}0.0007 \\
(0.2)\end{array}$ & $\begin{array}{c}-0.01 \\
(2.8)^{* * *}\end{array}$ & $\begin{array}{l}-0.008 \\
(2.5) * *\end{array}$ & $\begin{array}{c}-0.009 \\
(3.1)^{* * *}\end{array}$ & $\begin{array}{l}-0.007 \\
(2.4)^{*}\end{array}$ \\
\hline Federalism & $\begin{array}{l}-0.52 \\
(1.8)^{*}\end{array}$ & $\begin{array}{l}-0.22 \\
(1.1)\end{array}$ & $\begin{array}{l}-0.30 \\
(1.1)\end{array}$ & $\begin{array}{l}-0.36 \\
(1.4)\end{array}$ & $\begin{array}{l}-0.41 \\
(1.8)^{*}\end{array}$ & $\begin{array}{l}-0.18 \\
(0.9)\end{array}$ & $\begin{array}{l}-0.11 \\
(0.5)\end{array}$ \\
\hline Honesty & $\begin{array}{l}-0.05 \\
(0.3)\end{array}$ & $\begin{array}{l}0.16 \\
(1.1)\end{array}$ & $\begin{array}{l}0.21 \\
(1.5)\end{array}$ & $\begin{array}{c}0.28 \\
(2.6)^{* *}\end{array}$ & $\begin{array}{l}0.34 \\
(0.8)\end{array}$ & $\begin{array}{c}0.34 \\
(3.5)^{* * *}\end{array}$ & $\begin{array}{c}1.02 \\
(3.4)^{* * *}\end{array}$ \\
\hline Honesty $^{2}$ & & & & & $\begin{array}{l}-0.01 \\
(0.3)\end{array}$ & & $\begin{array}{c}-0.07 \\
(2.7) * * *\end{array}$ \\
\hline ENGOs & $\begin{array}{c}0.03 \\
(3.2)^{* * *}\end{array}$ & $\begin{array}{l}0.01 \\
(1.4)\end{array}$ & $\begin{array}{c}0.03 \\
(3.8)^{* * *}\end{array}$ & $\begin{array}{c}0.03 \\
(4.5)^{* * *}\end{array}$ & $\begin{array}{c}0.03 \\
(4.4)^{* * *}\end{array}$ & $\begin{array}{l}0.01 \\
(1.0)\end{array}$ & $\begin{array}{l}0.01 \\
(1.0) \\
\end{array}$ \\
\hline Constant & $\begin{array}{c}2.66 \\
(4.6)^{* * *}\end{array}$ & $\begin{array}{c}3.03 \\
(6.8)^{* * * *}\end{array}$ & $\begin{array}{c}2.68 \\
(5.4)^{* * *}\end{array}$ & $\begin{array}{c}3.46 \\
(7.5) * * *\end{array}$ & $\begin{array}{c}3.59 \\
(3.6)^{* * *}\end{array}$ & $\begin{array}{c}3.06 \\
(8.5) * * *\end{array}$ & $\begin{array}{c}1.63 \\
(2.4) * *\end{array}$ \\
\hline No. of Obs. & 68 & 69 & 67 & 70 & 70 & 70 & 70 \\
\hline $\mathrm{R}^{2}$ & 0.448 & 0.348 & 0.403 & 0.477 & 0.498 & 0.474 & 0.503 \\
\hline $\begin{array}{l}\text { DWH Test } \\
\text { Honesty }\end{array}$ & $\begin{array}{l}\mathrm{F}(1,55)= \\
.42 \\
p \text { value }= \\
.5184\end{array}$ & $\begin{array}{l}\mathrm{F}(1,57)= \\
.34 \\
p \text { value }= \\
.5650\end{array}$ & $\begin{array}{l}\mathrm{F}(1,54)= \\
2.73 \\
p \text { value }= \\
.1030\end{array}$ & $\begin{array}{l}\mathrm{F}(1,57)= \\
1.28 \\
p \text { value }= \\
.2634\end{array}$ & $\begin{array}{l}\mathrm{F}(1,57)= \\
1.46 \\
p \text { value }= \\
.2310\end{array}$ & $\begin{array}{l}\mathrm{F}(1,58)= \\
3.28 \\
p \text { value }= \\
.0753\end{array}$ & $\begin{array}{l}\mathrm{F}(1,58)= \\
4.46 \\
p \text { value }= \\
.0416\end{array}$ \\
\hline $\begin{array}{l}\text { DWH Test } \\
\text { Openness }\end{array}$ & $\begin{array}{l}\mathrm{F}(1,55)= \\
.06 \\
p \text { value }= \\
.8146\end{array}$ & $\begin{array}{l}\mathrm{F}(1,57)= \\
.05 \\
p \text { value }= \\
.8308\end{array}$ & $\begin{array}{l}\mathrm{F}(1,54)= \\
1.33 \\
p \text { value }= \\
.2531\end{array}$ & $\begin{array}{l}\mathrm{F}(1,57)= \\
1.53 \\
p \text { value }= \\
.2217\end{array}$ & $\begin{array}{l}\mathrm{F}(1,57)= \\
0.48 \\
p \text { value }= \\
.4931\end{array}$ & $\begin{array}{l}\mathrm{F}(1,58)= \\
.80 \\
p \text { value }= \\
.3742\end{array}$ & $\begin{array}{l}\mathrm{F}(1,58)= \\
1.02 \\
p \text { value }= \\
.3179\end{array}$ \\
\hline $\begin{array}{l}\text { Ramsey } \\
\text { Reset Test }\end{array}$ & $\begin{array}{l}\mathrm{F}(3,60)= \\
.20 \\
p \text { value }= \\
.8926\end{array}$ & $\begin{array}{l}\mathrm{F}(3,61)= \\
1.76 \\
p \text { value }= \\
.1637\end{array}$ & $\begin{array}{l}\mathrm{F}(3,59)= \\
.10 \\
p \text { value }= \\
.9594\end{array}$ & $\begin{array}{l}\mathrm{F}(3,59)= \\
4.08 \\
p \text { value }= \\
.0106\end{array}$ & $\begin{array}{l}\mathrm{F}(3.59)= \\
1.58 \\
p \text { value }= \\
0.2041\end{array}$ & $\begin{array}{l}\mathrm{F}(3,59)= \\
2.18 \\
p \text { value }= \\
.1000\end{array}$ & $\begin{array}{l}\mathrm{F}(3,59)= \\
1.02 \\
p \text { value }= \\
.3896\end{array}$ \\
\hline Mean VIF & 1.76 & 1.75 & 1.83 & 5.33 & 85.05 & 5.43 & 86.85 \\
\hline
\end{tabular}

Notes: t-statistics in parenthesis. ${ }^{* *}(* *)[*]$ Statistically significant at $1(5)$ [10] percent level. 
Table 4: Individual Pollutant Regressions

\begin{tabular}{|c|c|c|c|c|c|c|}
\hline Variable & $\begin{array}{c}\text { Air } \\
\text { Pollution }\end{array}$ & $\begin{array}{c}\text { Water } \\
\text { Pollution }\end{array}$ & $\begin{array}{c}\text { Waste } \\
\text { Pollution }\end{array}$ & $\begin{array}{l}\text { Ecosystem } \\
\text { Mgmt (1) }\end{array}$ & $\begin{array}{l}\text { Ecosystem } \\
\text { Mgmt (2) }\end{array}$ & $\begin{array}{c}\text { Natural } \\
\text { Resource } \\
\text { Mgmt }\end{array}$ \\
\hline GDP & $\begin{array}{l}0.0001 \\
(2.6) * *\end{array}$ & $\begin{array}{c}-0.0001 \\
(0.7)^{*}\end{array}$ & $\begin{array}{c}0.00007 \\
(1.6)^{*}\end{array}$ & $\begin{array}{c}-0.0002 \\
(2.1)^{*}\end{array}$ & $\begin{array}{c}-0.0005 \\
(2.0)^{*}\end{array}$ & $\begin{array}{l}-0.0001 \\
(1.1)\end{array}$ \\
\hline GDP $^{2}$ & & $\begin{array}{c}2.39 * 10^{-8} \\
(2.0)^{*}\end{array}$ & & $\begin{array}{l}2.79 * 10^{-8} \\
(3.3)^{* * *}\end{array}$ & $\begin{array}{l}9.97 * 10^{-8} \\
(1.7)^{*}\end{array}$ & $\begin{array}{c}2.06^{*} 10^{-8} \\
(2.7)^{* *}\end{array}$ \\
\hline GDP $^{3}$ & & & & & $\begin{array}{c}-4.08 * 10^{-12} \\
(1.3)\end{array}$ & \\
\hline \%Urban & $\begin{array}{l}-0.006 \\
(1.0)\end{array}$ & $\begin{array}{c}-0.004 \\
(0.5)\end{array}$ & $\begin{array}{l}-0.01 \\
(1.2)\end{array}$ & $\begin{array}{c}-0.001 \\
(0.2)\end{array}$ & $\begin{array}{c}0.0007 \\
(0.1)\end{array}$ & $\begin{array}{c}-0.001 \\
(0.2)\end{array}$ \\
\hline Openness & $\begin{array}{c}-0.003 \\
(0.9)\end{array}$ & $\begin{array}{l}-0.007 \\
(1.8)^{*}\end{array}$ & $\begin{array}{c}-0.0009 \\
(0.2) \\
\end{array}$ & $\begin{array}{c}-0.01 \\
(4.3)^{* * *}\end{array}$ & $\begin{array}{c}-0.01 \\
(3.2)^{* * *}\end{array}$ & $\begin{array}{l}-0.010 \\
(2.6)^{* *}\end{array}$ \\
\hline Federalism & $\begin{array}{c}-1.17 \\
(2.9)^{* * *}\end{array}$ & $\begin{array}{l}-0.52 \\
(1.5)\end{array}$ & $\begin{array}{l}-0.58 \\
(1.2)\end{array}$ & $\begin{array}{c}-1.14 \\
(3.3)^{* * *}\end{array}$ & $\begin{array}{c}-1.02 \\
(2.4)^{* *}\end{array}$ & $\begin{array}{l}-0.21 \\
(0.6)\end{array}$ \\
\hline Honesty & $\begin{array}{l}-0.01 \\
(0.1) \\
\end{array}$ & $\begin{array}{l}0.17 \\
(1.4) \\
\end{array}$ & $\begin{array}{c}0.23 \\
(1.7)^{*}\end{array}$ & $\begin{array}{c}0.33 \\
(3.5)^{* * *}\end{array}$ & $\begin{array}{l}0.28 \\
(0.7) \\
\end{array}$ & $\begin{array}{c}0.34 \\
(3.5)^{* * *}\end{array}$ \\
\hline Honesty $^{2}$ & & & & & $\begin{array}{l}-.001 \\
(0.03)\end{array}$ & \\
\hline ENGOs & $\begin{array}{c}0.03 \\
(3.5)^{* * *}\end{array}$ & $\begin{array}{l}0.01 \\
(0.9)\end{array}$ & $\begin{array}{c}0.03 \\
(3.8)^{* * *}\end{array}$ & $\begin{array}{c}0.03 \\
(3.8)^{* * *}\end{array}$ & $\begin{array}{c}0.03 \\
(4.5)^{* * *}\end{array}$ & $\begin{array}{l}0.01 \\
(1.0)\end{array}$ \\
\hline $\begin{array}{l}\text { Federalism } \\
\text { *Openness }\end{array}$ & $\begin{array}{c}0.01 \\
(2.3)^{* *}\end{array}$ & $\begin{array}{l}0.005 \\
(1.2)\end{array}$ & $\begin{array}{l}0.005 \\
(1.0)\end{array}$ & $\begin{array}{c}0.01 \\
(3.8)^{* * *}\end{array}$ & $\begin{array}{c}0.01 \\
(2.3)^{* *}\end{array}$ & $\begin{array}{c}0.0004 \\
(0.1)\end{array}$ \\
\hline Constant & $\begin{array}{c}2.75 \\
(5.0)^{* * *}\end{array}$ & $\begin{array}{c}3.47 \\
(7.9)^{* * *}\end{array}$ & $\begin{array}{c}2.72 \\
(5.4)^{* * *}\end{array}$ & $\begin{array}{c}3.59 \\
(8.4)^{* * *}\end{array}$ & $\begin{array}{c}3.78 \\
(3.7)^{* * *}\end{array}$ & $\begin{array}{c}3.07 \\
(8.1)^{* * *}\end{array}$ \\
\hline No. of Obs. & 68 & 69 & 67 & 70 & 70 & 70 \\
\hline $\mathrm{R}^{2}$ & 0.471 & 0.399 & 0.408 & 0.517 & 0.520 & 0.474 \\
\hline $\begin{array}{l}\text { DWH Test } \\
\text { Honesty }\end{array}$ & $\begin{array}{l}\mathrm{F}(1,54)= \\
.37 \\
p \text { value }= \\
.5430\end{array}$ & $\begin{array}{l}\mathrm{F}(1,56)= \\
.32 \\
p \text { value }= \\
.5754\end{array}$ & $\begin{array}{l}\mathrm{F}(1,53)= \\
2.81 \\
p \text { value }= \\
.0997\end{array}$ & $\begin{array}{l}\mathrm{F}(1,56)= \\
1.36 \\
p \text { value }= \\
.2493\end{array}$ & $\begin{array}{l}\mathrm{F}(1,56)= \\
0.73 \\
p \text { value }= \\
.3968\end{array}$ & $\begin{array}{l}\mathrm{F}(1,57)= \\
3.22 \\
p \text { value }= \\
.0779\end{array}$ \\
\hline $\begin{array}{l}\text { DWH Test } \\
\text { Openness }\end{array}$ & $\begin{array}{l}\mathrm{F}(1,54)= \\
.18 \\
p \text { value }= \\
.6692\end{array}$ & $\begin{array}{l}\mathrm{F}(1,56)= \\
.02 \\
p \text { value }= \\
.8930\end{array}$ & $\begin{array}{l}\mathrm{F}(1,53)= \\
1.39 \\
p \text { value }= \\
.2444\end{array}$ & $\begin{array}{l}\mathrm{F}(1,56)= \\
1.67 \\
p \text { value }= \\
.2009\end{array}$ & $\begin{array}{l}\mathrm{F}(1,56)= \\
2.24 \\
p \text { value }= \\
.1425\end{array}$ & $\begin{array}{l}\mathrm{F}(1,57)= \\
.70 \\
p \text { value }= \\
.4078\end{array}$ \\
\hline $\begin{array}{l}\text { Ramsey } \\
\text { Reset Test }\end{array}$ & $\begin{array}{l}\mathrm{F}(3,59)= \\
.30 \\
p \text { value }= \\
.8230\end{array}$ & $\begin{array}{l}\mathrm{F}(3,60)= \\
1.76 \\
p \text { value }= \\
.1660\end{array}$ & $\begin{array}{l}\mathrm{F}(3,58)= \\
.04 \\
p \text { value }= \\
.9873\end{array}$ & $\begin{array}{l}\mathrm{F}(3,58)= \\
2.19 \\
p \text { value }= \\
.0990\end{array}$ & $\begin{array}{l}\mathrm{F}(3,58)= \\
1.24 \\
p \text { value }= \\
0.3022\end{array}$ & $\begin{array}{l}\mathrm{F}(3,58)= \\
2.13 \\
p \text { value }= \\
.1062\end{array}$ \\
\hline Mean VIF & 2.35 & 5.55 & 2.42 & 5.41 & 80.67 & 5.52 \\
\hline
\end{tabular}

Notes: t-statistics in parenthesis. $* * *(* *)[*]$ Statistically significant at 1 (5) [10] percent level. 